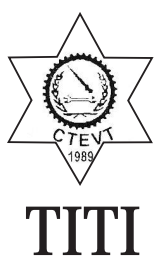

Journal of

Training and Development

2016, Volume 2

ISSN: 2392-456X(Print)

DOI: http://dx.doi.org/10.3126/jtd.v2i0.15431

ISSN: 2392-4578(Online)

\title{
Challenges of Sustainable Development of TVET Programs and Projects
}

\author{
Ramhari Lamichhane, PhD \\ Member secretary/CEO \\ Council for Technical Education and Vocational Training \\ Sanothimi, Bhaktapur, Nepal \\ Email for Correspondence:rhlamichhane@gmail.com
}

\begin{abstract}
Education is a key to open the door of human development and TVET is master key to open the door of economic development of the world. Therefore, all most all countries have given high priority for TVET to empower their human capital and economic development. Despite their initiatives, majority of them could not achieve sustainable development of TVET. There are different challenges and issues that are hindering on it. This paper describes on brief introduction on sustainable development and sustainable TVET or green TVET. It also highlights the major challenges of sustainable development of TVET.
\end{abstract}

Keywords: Technical education, vocational training and sustainable development

What is Sustainable Development (SD)? According to International Institute for Sustainable Development (2015), "Sustainable development is development that meets the needs of the present without compromising the ability of future generations to meet their own needs. It contains within it two key concepts:

- the concept of needs, in particular the essential needs of the world's poor, to which overriding priority should be given; and

- the idea of limitations imposed by the state of technology and social organization on the environment's ability to meet present and future needs."

Considering the above definition, we have to categorize the needs at different level because it differs from people to people, group to group, society to society, country to country. Therefore, needs are based on economic and social context. For example, if you listed clean air to breathe, but also listed a car for transportation, your needs might conflict. What happens when a company's need for cheap labor conflicts with workers' needs for livable wages? Or when individual families' needs for firewood conflict with the need to prevent erosion and conserve topsoil? Or when one country's need for electricity results in acid rain that damages another country's lakes and rivers?

Therefore, identification of needs and prioritize them to fulfill the needs of majority of people without 
damaging economic, social, cultural and environment aspects is considered as sustainable development (World Bank, 2001).

What is Sustainable TVET or Green TVET? Green skills are also known as sustainable development skills. It refers to skills, knowledge, and attitudes needed by labor to support and promote sustainable social and economic development and to improve environment friendly in business and communities. 'Green skills' is generic skills, which include minimizing the use of resources, reducing of greenhouse gas emissions, recycling, using environment friendly products, protection of natural environment, and so on (UNEVOC, 2005). "Green jobs" are defined as jobs that reduce the environmental impact of enterprises and economic sectors, ultimately to levels that are sustainable. This definition covers work in agriculture, industry, services and administration that contributes to preserving or restoring the quality of the environment while also meeting the criteria for decent work adequate wages, safe conditions, workers' rights, social dialogue and social protection (ILO, 2011).

Schumacher (1974) defined them as: 'technologies with a human face' aimed to enable people to earn a sustainable living. He proposed eight criteria to assess technology:

1. Appropriate technology best suits the needs and lifestyle of the people using it.

2. Appropriate technology should not damage the environment and ecosystem, and should be sustainable.

3. Appropriate technology should keep costs within the economic means of a community.

4. Appropriate technology should use locally available resources as far as possible.

5. Appropriate technology should enable local workers to earn a living.

6. Appropriate technology should increase self reliance.

7. Appropriate technology should use renewable sources of energy wherever possible, and should be economical in its use of non-renewable resources.

8. Appropriate technology should fit with its social and cultural environment.

Therefore, sustainable TVET program is that which imparts knowledge, skills and attitude for gainful economic value without damaging social, cultural and environmental elements.

Therefore, TVET Programs which contribute to impart knowledge, skills, and attitude for green jobs and develops workforce for sustainable and environment friendly economic development is called sustainable development of TVET programs.

\section{Challenges of Sustainable Development of TVET Programs and Projects}

Technical and Vocational Education and Training (TVET) policies and programs are developed and implementing in different countries. As a global agendas or goals such as EFA, MDGs and SDGs set in different periods. Despite the global and countries efforts, many countries could not achieve its sustainable TVET programs. However, some of the countries such as Germany, Switzerland, Australia, South Korea, Singapore and other developed countries able to develop sustainable TVET programs and contributed for sustainable development (UNEVOC, 2005). Considering the context of developing countries, there are many challenges of sustainable development of TVET programs. Following are the major challenges.

\section{Awareness on Sustainable Development Approaches or Models}

There are huge gaps in education system to learn on sustainable development. School education, TVET and higher education curricula are not relevant with sustainable development approaches. Therefore, we have to do campaign to bring awareness on SD and develop educational system to contribute SD. Wilson (2011) also states that in developing and least development countries there are huge gap in education system 
and the awareness in respect to sustainable development is vital to remove this gap.

\section{Development of TVET programs and projects for quality of life rather than immediate poverty reduction}

In economically deprived situation, people are worried with their day to day livelihood problems. Therefore, TVET programs are implementing to fulfill their immediate needs rather than long term quality of life. As a result people are struggling to survive in the poverty situation. $\mathrm{Li}$ (2014) also reveals that TVET programs provide practical skill and life skills which further helps them to fulfill their long term needs and aspirations.

\section{Match between demand and supply of TVET Programs}

In developing countries, there is still huge gap between skills required by the employers and skills provided by TVET institutions. It is happening due to the lack of professional corporate culture, coordination between both demand and supply sides and lack of resources to do market research. As a result, graduates of TVET are either unemployed or do not get gainful employment. Seen in this light, TVET is more closely aligned with productive activities -sometimes survival strategies- or with those which are doable and result from the nature of their contexts, than to the need to train in order to satisfy the demand of a formal market or respond to the exigencies of technological development as dictated by modernity (Pieck, 2015).

\section{High Quality TVET for Sustainable Development}

Due to the lack of resources and low priority for TVET sector, our programs are in very low level of quality such as lack of qualified instructors, equipped labs and workshops, and adequate training materials. Similarly, students are not learning well due to the lack of proper working environment such as poor occupational health and safety measures, standards of working procedures and less opportunity for appropriate practical skills. As a cultural barrier, majority of students are from poor economic background. However, examples in many countries abound of programs that have developed successful strategies for enabling low-income populations to gain entry to the world of work; strategies that have reinforced the local economy, and have generated new forms of participation. Such lessons are concerned with the need to have a social focus when addressing TVET programs in developing countries, a focus which is very much at odds with the prevailing tendency.

\section{To break traditional approaches of TVET} Our TVET programs are still incorporate only hard skills not soft skills such as problem solving, communication, negotiation, social values, environment protections, entrepreneurial skills and other skills which contribute for social and economic development in a sustainable way. Similarly, our teaching and learning methodologies are teacher centered not learner centered. Therefore, students are lacking employability skills. Kumar (2013) also argue that TEVT programme should incorporate both hard skill and soft skill for its sustainability.

\section{Adoption of innovation, technology and global competitiveness in TVET}

Innovation, apply appropriate technology and make globally competiveness in TVET are the key aspects for sustainable TVET (Wilson, 2011). We are lacking behind on these aspects due to the poor management, lack of resources and commitment. Therefore, most of our graduates are not getting and creating jobs.

\section{Conclusions}

Sustainable Development is backbone of present and future economic development of the country. It can be possible with the human capital having TVET with green or sustainable skills. For These skills 
contribute to create green jobs, green environment and green society. Ultimately, it contributes for global sustainable development. There are many challenges of sustainable development of TVET but, we can overcome such challenges. Challenges can be converted into opportunities if we addressed sustainable development of TVET components in all stage of TVET cycle such as pre training, on training and post training stages. It means training program should be developed based on market demand, involvement of employers in all stages, course should have greening skills, teaching and learning methodology must be low teacher centered and high self learning environment i.e, practical exposure, group works, industry exposure, cognitive and problem solving skills, exposure to green jobs and green industry, entrepreneurship skills, and appropriate technology which reduces the energy and resources. Similarly, there should be strong linkages with employers and financial institutions for self employment generation for post TVET stages. It gives exposure to graduates on greening jobs and creates green jobs and environment.

\section{References}

International Institute for Sustainable Development. (2015). Sustainable development. Retrieved on 16 February 2016 from https://www.iisd.org/topic /sustainable-development

International Labor Organisation. (2011). Skills for green 4 jobs: a global view. Paris: Author

Kumar, A. (2013). TVET problem and prospects. New Delhi: S Chand \& Co.

Li, X. (2014). Education for sustainable development. Singapore: Penguin publishers

Pieck, E. (2015). TVET and sustainable development. Iberoamerican University, Mexico. Retrieved on 16 February 2016 from https://norrag.word press.com/2015/05/28/tvet-and-sustainable development-learning-from-experience-what and- hy-do-we-wait-for/
Schumacher, EF.(1974). Small is beautiful. New York: Sage Publication

UNEVOC. (2005). Technical and vocational education and training for sustainable development: the challenges of implementation. Berlin: Author

Wilson, J. (2011). TVET in an international context. New York: Sage Publication

World Bank.(2001). What is sustainable development? Retrieved on 17 February 2016 from http://www.worldbank.org /depweb/english/sd.html 